\title{
Effect of crude petroleum on water repellency in a clayey alluvial soil
}

\author{
D. C. Marín-García ${ }^{1}$ R. H. Adams ${ }^{1}$ - R. Hernández-Barajas ${ }^{1}$
}

Received: 5 August 2014/Revised: 2 May 2015 / Accepted: 29 June 2015/Published online: 23 July 2015

(C) Islamic Azad University (IAU) 2015

\begin{abstract}
Water repellency was studied in a clayey soil contaminated with light $\left(36.6^{\circ} \mathrm{API}\right)$, medium $\left(27.4^{\circ} \mathrm{API}\right)$, and heavy $\left(15.0^{\circ} \mathrm{API}\right)$ crude oils at concentrations of 1,2 , 4 , and $8 \%$. Higher water drop penetration times (WDPTs) were observed in dry soil as the density and concentration of petroleum increased, resulting in logarithmic functions which could be modeled from API gravity and oil concentration $\left(R^{2}=0.986\right)$. WDPTs varied from 2.1 to $8.7 \mathrm{~s}$ with light crude, 11.1 to $44.9 \mathrm{~s}$ for medium crude, and 39.4 to $134.5 \mathrm{~s}$ for heavy crude. Only heavy crude-contaminated soil, at $>2 \%$ resulted in significant hydrophobicity. Critical moisture content in these hydrophobic soils was insignificant at moisture contents $>12.8 \%$ at $2 \%$ heavy crude and $>14.6 \%$ at $4 \%$ heavy crude. Only at a concentration of $8 \%$ heavy crude was the critical moisture content $(>17.2 \%)$ higher than that observed in the field during the dry season (14.8\%). Thus, only (clayey) soil contaminated with very high concentrations of heavy oil is likely to present hydrophobicity in this monsoon climate. This study shows that the development of models to describe soil water repellency may be useful to propose remediation criteria which reduce or avoid the risk of water repellency.
\end{abstract}

Keywords ${ }^{\circ}$ API $\cdot$ Critical moisture content . Hydrophobicity · Oil contamination

R. H. Adams

drrandocan@hotmail.com

1 División Académica de Ciencias Biológicas, Universidad Juárez Autónoma de Tabasco, Km 0.5 Carretera Villahermosa-Cárdenas, CP 86039 Villahermosa, Tab., Mexico

\section{Introduction}

One of the environmental problems associated with the petroleum industry is crude oil spills, causing soil contamination (Alves et al. 2012; Basumatary et al. 2012). The lack of environmental specifications for the restoration of contaminated soils constitutes one of the principal factors of uncertainty with respect to the effectiveness of remediation actions. Although many techniques are effective in reducing the overall hydrocarbon concentration in the soil (Volke and Velasco 2002), these methods do not necessarily restore the physical and chemical properties of the soil that may be affected by petroleum spills, impeding future site use (Adams et al. 2008b; Lu et al. 2010).

Contamination of soil arising from spills is one of the most limiting factors to soil fertility and hence crop productivity (Onwurah et al. 2007). One of the major impacts of petroleum spills in a terrestrial environment is on the soil-water-plant interaction. Adams et al. (2008a) studied this kind of interaction with the observation of reduced field capacity (humidity) and formation of water repellency in hydrocarbon-contaminated soil. Other authors have also observed extreme water repellency in soils affected by petroleum spills (Li et al. 1997; Roy and McGill 1998; Quyum 2000; Sublette et al. 2010; Edenborn and Zenone 2007; Nieber et al. 2011). One of the reasons given for this impact is the formation of a thin film of no-, or low-polarity compounds (i.e., hydrocarbons), which cover the polar or charged surfaces of the soil organic matter (SOM) and clays, effectively interfering with the electrostatic interaction between soil particles and water (Adams et al. 2008b).

Adams et al. (2008a), Shakesby et al. (2000) Dekker and Ritsema (1994), as well as Li et al. (1997) drew attention to the fact that the soil water repellency was strongly influenced by the water content of the soil. Usually, soil 
surfaces are covered with a thin film of water, but when the soil dries completely, water repellent organic compounds (such as hydrocarbons) may attach to the charged soil surfaces through van der Waals forces, causing the soil surface not to be available to interact with water, thus reducing the retention of water and nutrients for plants. This may result in increased run-off and erosion, as well as the overall deterioration of soil structure, generating preferential flow pathways that cause the water infiltration that does occur, to be very uneven (Regalado et al. 2005; Jaramillo 2006; Pires et al. 2006; Leelamanie et al. 2008; Moody and Schlossberg 2010; Barton and Colmer 2011; Nieber et al. 2011).

Dekker and Ritsema (1994) observed that there was a water content below which the soil became water repellent and above which the soil was wettable. With this observation, they defined the concept of critical moisture content, or critical humidity. This refers to the moisture value that represents the limit between hydrophobic and wettable soil (Jaramillo 2005). Clothier et al. (2000) and Dekker et al. (2004) have suggested maintaining the soil above the critical water content as the best preventive technique to minimize the development of soil water repellency.

Crude petroleum is a complex mixture of hydrocarbons with different characteristics and physical and chemical properties (Zahed et al. 2010). The susceptibility of a hydrocarbon to microbial degradation varies with type and size of the hydrocarbon molecule; long-chain hydrocarbons and c-alkanes are known as recalcitrant to microbial degradation (Bagherzadeh-Namazi et al. 2008). Heavy crude and some fuels (such as fuel oil no. 6) are very viscous, and their migration tends to be more horizontal (surface flow) rather than by infiltration, whereas gasoline and low-viscosity oils easily penetrate the soil (Atlas 1981). Different soil types have different capacities with respect to the accumulation of contaminants (Gutiérrez and Zavala 2002). The soil clays and organic material favor the immobilization of petroleum compounds (Bohn et al. 1993). Particulate SOM, acting as a reservoir of hydrophobic waxes, plays a substantial role in the development of soil water repellency (Schlossberg et al. 2005).

The purpose of the present study was to evaluate the effect of different types of crude petroleum, on water repellency and critical moisture content in a clayey alluvial soil representative of the petroleum-producing region of southeastern Mexico, to help establish criteria for the evaluation of contaminated and remediated sites. This research was carried out between January 2011 and July 2012 in the Remediation Laboratory of the Universidad Juárez Autónoma de Tabasco, Villahermosa, Tabasco, Mexico.

\section{Materials and methods}

\section{Sampling and soil physical-chemical characterization}

The soil collected for this study comes from the Tabasco lowlands, Mexico, which has a tropical monsoon climate (Am) in the Köppen classification system (Peel et al. 2007; Adams et al. 2008a). Soils in the area are generally moist, not only due to the local precipitation, but because of runoff received from a much wider area, including the Chiapas highlands (Mexico) and neighboring parts of Guatemala. The soil has been classified as a Vertisol according to soil profiles and in agreement with Palma and Triano (2007), and this was confirmed by the gilgai microrelief observed during the dry season. The area has an annual average precipitation of $\sim 1800 \mathrm{~mm}$ and an average annual temperature of $\sim 26{ }^{\circ} \mathrm{C}$ (West et al. 1987). Soil was sampled in the Buena Vista area in the Cardenas Municipality, in Tabasco State, Mexico, at coordinates (UTM) 15Q 406447E and 2001730N. Approximately $60 \mathrm{~kg}$ of soil were collected with a straight shovel from the upper $30 \mathrm{~cm}$ of soil, in this case to sample the most active and important part for root development for pastures and crops (Porta et al. 1999). Chemical and physical characteristics of the uncontaminated soil were determined according to

Table 1 Characterization of uncontaminated soil

\begin{tabular}{lll}
\hline Variables & Value & Unit \\
\hline Particle density & $2.36 \pm 0.01$ & $\mathrm{~g} \mathrm{~cm}^{-3}$ \\
Bulk density & $1.10 \pm 0.003$ & $\mathrm{~g} \mathrm{~cm}^{-3}$ \\
$\mathrm{pH}(1: 2)$ & $7.18 \pm 0.06$ & \\
Porosity & $53.30 \pm 0.12$ & $\%$ \\
Field capacity & $36.74 \pm 1.21$ & $\%$ \\
Electrical conductivity & & \\
Conductivity & $0.146 \pm 0.003$ & $\mathrm{dS} \mathrm{m}$ \\
Organic matter & $3.77 \pm 0.05$ & $\%$ \\
$\mathrm{~N}$ & $0.19 \pm 0.01$ & $\%$ \\
Texture & $\mathrm{Clayey}$ & \\
Sand & $0.7 \pm 0.07$ & $\%$ \\
Silt & $39.3 \pm 0.36$ & $\%$ \\
Clay & $60 \pm 0.28$ & $\%$ \\
P olsen & $23.38 \pm 10.16$ & $\mathrm{mg} \mathrm{kg}^{-1}$ \\
$\mathrm{Cation}^{-1}$ exchange capacity & $31.77 \pm 0.56$ & $\mathrm{Cmol} \mathrm{kg}$ \\
$\mathrm{Ca}^{++}$ & $24.08 \pm 0.87$ & $\mathrm{Cmol} \mathrm{kg}^{-1}$ \\
$\mathrm{Mg}^{++}$ & $1.62 \pm 0.03$ & $\mathrm{Cmol} \mathrm{kg}$ \\
$\mathrm{Na}^{+}$ & $0.43 \pm 0.01$ & $\mathrm{Cmol} \mathrm{kg}$ \\
$\mathrm{K}^{+}$ & $0.68 \pm 0.03$ & $\mathrm{Cmol} \mathrm{kg}^{-1}$ \\
\hline
\end{tabular}

Values are means $(n=3)$ 
Mexican Official Norm NOM-021-SEMARNAT-2000 (SEMARNAT 2002). These values are shown in Table 1, as an indication of the characteristics of the starting material (soil) used in this study.

The value for bulk density found corresponds to clayey soils. This soil has a neutral $\mathrm{pH}$, with a relatively high organic matter content ( $\mathrm{SOM}>3.6 \%$ ), as well as a high content of phosphorous, calcium, potassium, and a medium content of magnesium. Salinity was negligible (EC $<1 \mathrm{dS} \mathrm{m}^{-1}$ ), and the soil had a high cation exchange capacity, according to the classification system presented in the previously mention norm. The quantity of exchangeable cations with respect to the amount of clay present in the soil (base status) was $44.68 \mathrm{cmol}(+) / \mathrm{kg}$ clay, corresponding to a soil with a relatively high inherent fertility, according to the Australian Soil Classification System (Isabell 1996). With respect to water repellency, the water drop penetration time (WDPT) indicated null repellency according to the classification system proposed by King (1981).

\section{Selection and characterization of crude petroleum}

Three crude petroleums were selected with different densities expressed as API gravities. Light crude was obtained from an oil spill in Cumuapa 2da Sección, in the Municipality of Cunduacán, Tabasco. Medium crude was collected from the Tajón 101 oil well in the Puerto Ceiba communal farming unit (ejido), in the Paraíso Municipality of Tabasco. Heavy crude was obtained from an unfinished wellhead (no. 1459) of the Texistepec Mining Unit in Texistepec Municipality, Veracruz. These three crude petroleums were characterized for API gravity ( $\left.{ }^{\circ} \mathrm{API}\right)$, using the ASTM-D 1298-85 hydrometer method by employing different hydrometers: thermo-hydrometer ASTM 54HL 29/41 for light crude, ASTM 53HL 19/31 for medium crude, and ASTM 52HH 9/21 for heavy crude (ICL Calibration Laboratories, Inc., Stuart, FL, USA).

The separation of crude petroleum into group fractions was carried out using column chromatography with selective solvents to determine the proportions of aliphatics, aromatics, polars and resins, and asphaltenes by using the method employed by Díaz et al. (2003). The characterization of the crude petroleums used in this study is presented in Table 2.

\section{Soil contamination}

Soil was dried, ground, and sieved (sieve size $2 \mathrm{~mm}$ ), and then contaminated with light, medium, and heavy crude at four concentrations: $1,2,4$, and $8 \%$ (dry weight basis). One and a half kilograms of processed soil was contaminated with each concentration. The mixture of soil and crude oil was homogenized using a semi-professional mixer (KitchenAid 600, Whirlpool México S.A. de C.V., Nuevo León) and subsequently run through an electric grinder. The grinder was a common type used to prepare nixtamal, manual converted to electric power, with a cutting spoon of galvanized plating, with a 2-hp motor, $110 \mathrm{~V}$ (Distributor: Casa Matus, Villahermosa, Tabasco). The ground material was then remixed on the electric mixer for $5 \mathrm{~min}$. A completely randomized experimental design was used including triple replicates ( 1 soil type $\times 3$ crude oil types $\times 4$ concentrations $\times 3$ replicates) producing 36 experimental units plus three uncontaminated controls. The processed and contaminated soil was placed in sealed cans, each with a 3-1 capacity. This material was later used for analysis.

\section{Water repellency}

Water repellency was measured by two methods. The molarity ethanol drop (MED) method was used to determine severity of water repellency and consists in measuring the molarity of ethanol in a drop of solution that allows the drop absorbs in $<10 \mathrm{~s}$ in dry, sieved soil (Letey et al. 2000; Roy and McGill 2002). In 2008, Adams et al. applied an exponential decomposition regression to these data to increase the precision of this determination. Using the regression equation, the ethanol molarity corresponding to a solution penetration time of $10 \mathrm{~s}$ can be calculated. Likewise, the regression function can be used to calculate the WDPT.

The WDPT measures the amount of time it takes for a drop of pure water to penetrate dry sieved soil. This method may be very difficult or impractical for soils with very high water repellency (with penetration times of 1000s of seconds). To simplify this method for hydrocarbon-contaminated, water repellent soils, Adams et al. (2008a) used data from the MED determination, employing the exponential decomposition regression equation. The extrapolation of this equation to a zero ethanol concentration (i.e., pure water) was used by these authors to calculate the value of WDPT indirectly. This same method was used in this experiment, and the water repellency results were classified according to the scheme proposed by King (1981).

\section{Critical moisture content}

Critical moisture content is the soil water content above which the soil does not present water repellency (Dekker and Ritsema 1994). This was determined by measuring the WDPT directly, at different soil humidities. One hundred grams of dry soil was placed in a covered plastic container. The soil therein was moistened gradually by spraying with 
Table 2 Characterization of crude oils

\begin{tabular}{llll}
\hline & \multicolumn{2}{l}{ Type of crude oil } \\
\cline { 2 - 4 } & Light & Medium & Heavy \\
\hline Ranges ${ }^{\circ}$ API & $>31.1$ & $22.3-31.1$ & $10.0-22.3$ \\
${ }^{\circ}$ API obtained & 36.6 & 27.4 & 15.0 \\
Relative density $\left(\mathrm{g} \mathrm{cm}^{-3}\right)$ & 0.84 & 0.89 & 0.97 \\
Asphaltenes (\%) & $2.89 \pm 0.10$ & $5.19 \pm 0.01$ & $17.62 \pm 0.40$ \\
Polars and resins (\%) & $4.72 \pm 0.01$ & $7.83 \pm 0.01$ & $19.43 \pm 0.20$ \\
Aliphatics (\%) & $74.55 \pm 0.10$ & $67.69 \pm 0.01$ & $40.94 \pm 0.60$ \\
Aromatics (\%) & $17.84 \pm 0.01$ & $19.29 \pm 0.01$ & $22.02 \pm 0.30$ \\
\hline
\end{tabular}

water and mixing manual mixing until a drop of water could penetrate rapidly $(<1 \mathrm{~s})$.

Subsequently, the soil was let air-dry for $30 \mathrm{~min}$, mixed well, and then replaced in the seal plastic container, where the moisture was allowed to stabilize for $2 \mathrm{~h}$ before the next measurement. Using this procedure, the penetration time was measured at five different moisture contents and the results were graphed to obtain the correlation between moisture content and water penetration time. The data typically corresponded to an exponential function, and the regression equation from this function was used to calculate the soil moisture at which a drop of water could penetrate the soil in $<5$ and $60 \mathrm{~s}$, corresponding to the values proposed by King (1981) for non-repellent and slightly repellent soil. The critical moisture contents determined by this method were compared to the in situ (field) moisture content as determined from a soil sample taken on the last day of the dry season, when the soil is driest and most vulnerable to present water repellency, just before the first summer rains, in this tropical monsoon climate.

\section{Results and discussion}

\section{Persistence of water repellency (WDPT)}

The WDPTs measured in the different treatments were highly significant. Applying the classification system of King (1981), the water repellency for light-crude-oil-contaminated soil was non-repellent or only slightly repellent, even at petroleum concentrations of up to $8 \%$. With this oil, the maximum WDPT was only $9 \mathrm{~s}$. With soil contaminated with medium crude, the WDPT were higher, but still only in the slightly repellent range (11-45 s). However, for soil contaminated with the heavy crude, the values rose much more sharply from $39 \mathrm{~s}$ at $1 \%$ oil (only slightly repellent) to above $80 \mathrm{~s}$ at $2 \%$ oil and increasing up to more than $2 \min (135 \mathrm{~s})$ for soil contaminated at $8 \%$. At all concentrations $\geq 1 \%$ of crude oil, the soil was classified as strongly repellent (see Fig. 1).

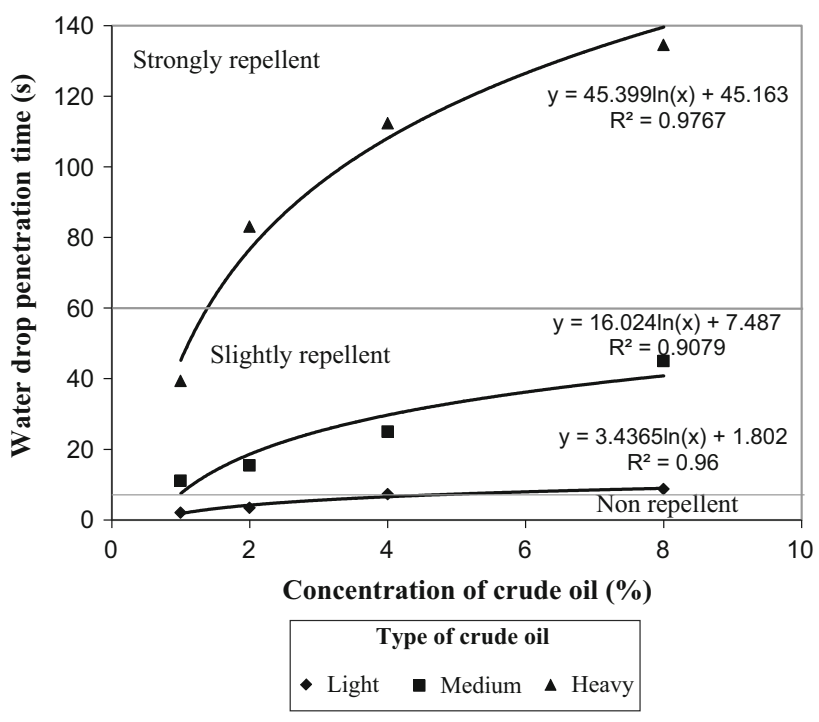

Fig. 1 Correlation between WDPT and concentration of crude oil $(\%)$

The oil concentration versus WDPT data for the three crude petroleum considered in this study corresponds to logarithmic functions with relatively good correlations according to coefficients of determination $\left(R^{2}=\right.$ 0.906-0.976). This type of behavior has been described by Freundlich (1926) as a surface phenomenon in which the adsorption energy decreases logarithmically as the surface becomes more covered. Since this first publication of the Freundlich absorption isotherm, soil scientists have encountered many compounds which present this kind of phenomenon (see, for example, the excellent review by USDA scientist (Goldberg 2005)). The results of this study are congruent with this concept of surface covering.

As the concentration of crude petroleum becomes greater in the soil, its sorption onto the soil surface increases, and consequently, the soil water repellency also increases. The three types of crude petroleum confer different levels of soil water repellency persistence. As the petroleum density increases, the rate at which the WDPT values increase is greater. The heavy crude had the greatest 
impact and may be attributed to the higher content of molecules with polar functional groups (polars and asphaltenes) in this oil. This would be congruent with the model of soil water repellency proposed by Litvina et al. (2003), in which the hydrocarbons with a greater abundance of polar functional groups (corresponding to the more weathered or burned products of crude petroleum) play a pivotal role in the adsorption of the hydrocarbon mix to the soil surfaces, acting as chemical bridges between the SOM and the majority of extremely low or non-polar hydrocarbons.

\section{Critical moisture content}

Critical moisture content was determined in those soil samples which presented strong water repellency (WDPT $>60 \mathrm{~s}$ ), which was the case with the highest three concentrations of heavy crude petroleum (Fig. 2).

Although the contaminated soil showed severe water repellency in the laboratory, in the field, this problem may not present itself for two reasons. One is the in situ moisture content of this clay soil. Even in the driest part of the year (May), the in situ moisture content was observed to be $14.83 \%$ on the soil surface and $15.50 \%$ in the cracks. As seen in Fig. 2, the critical moisture content for this soil contaminated with 2 and $4 \%$ heavy crude is below this value. For example, for the soil with $4 \%$ crude, the critical moisture content value was $13.7 \%$. This means that for the soil to present water repellency (above $60 \mathrm{~s}$ ), it would have to dry out to below this level. Since even during the driest part of the year, the soil moisture is higher than this, it is very unlikely that water repellency would be observed in the field. Only for the soil contaminated with $8 \%$ heavy crude was a critical moisture content value higher than the dry season (field) in situ moisture content encountered.

The second reason that water repellency may not be found in this kind of soil with vertic properties is the formation of cracks. During the dry season, when the soil is

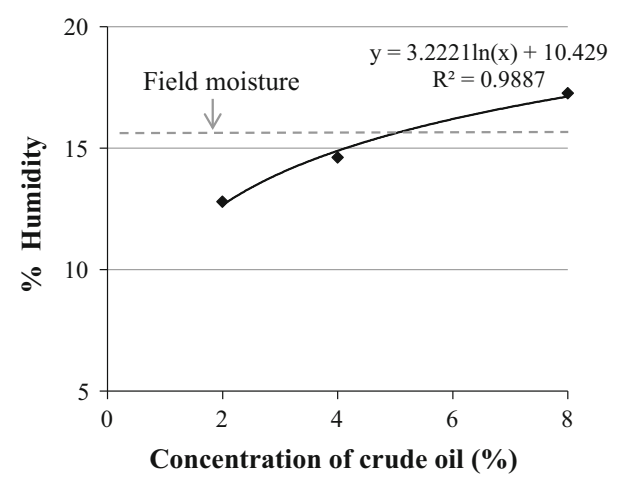

Fig. 2 Critical moisture content for heavy-crude-oil-contaminated soil potentially most vulnerable to water repellency problems (which would occur with the first rains following the drought), the soil forms deep cracks. At this site, the cracks are roughly between $60 \mathrm{~cm}$ and $1.2 \mathrm{~m}$. During the first rains, if water repellency was apparent on the surface, the water would run down into the cracks and be trapped. In the cracks, the in situ moisture content is a little higher and the soil could probably be slowly moistened from the bottom of the cracks both upward (by capillary action) and downward (by gravity as well as capillary action). Thus, even in the soil contaminated with up to $8 \%$ heavy crude, water repellency may not be a problem in this kind of soil with high shrink-swell properties.

Other authors have also observed this discrepancy between water repellency as measured in the laboratory and actual conditions in the field (Adams et al. 2008a; Guzmán and Adams 2014). For 2 years, Guzmán and Adams (2014) monitored the remediation of very clayey, hydrocarbon-contaminated sediments that had been treated using a chemical-biological stabilization technology. Parameters that focused on the soil-water relationship were evaluated (MED, WDPT, critical moisture content), and at the end of the evaluation period, the values of MED and WDPT (as determined in the laboratory) corresponded to levels of severe and strong water repellency, respectively. However, in the field, the pasture that had been planted as part of the treatment process did not show signs of water stress (wilting, yellowing, etc.). For this reason, the critical moisture content was determined and compared to the actual in situ moisture content during different parts of the year. The in situ moisture content (field) remained above the critical moisture content level throughout the monitoring, which the authors presented as a possible explanation for the discrepancy between field observations and laboratory determinations.

Likewise, Adams et al. (2008a) studied water repellency in clayey and sandy, petroleum-contaminated soils in a humid tropical environment. They observed that the sandy soil presented severe water repellency problems a relatively low petroleum concentrations, and this being much greater than that observed in the clayey soil. In that study, the authors mention that the values determined in the laboratory may not be representative of field conditions, and in the case of the clayey soil studied, even during the driest part of the year, the soil was abundantly moist (80\% of field capacity).

It is characteristic for sandy soils to have a relatively small surface area and low organic content (Roy and McGill 1998), they and are more prone to develop soil water repellency than finer soil textural classes due to the low specific surface area of sand (Schlossberg et al. 2005). This contributes to the problems caused by the formation of thin layers of hydrocarbons in soil: There is less reactive 
surface area to start with, and this is easily covered with oil-resulting in problems of water repellency. Ávila (2011) investigated a sandy soil contaminated with the same crude petroleums used in the present study, and at the same concentrations. He found that (in contrast to clayey soils) the sandy soil presented severe water repellency at all concentrations tested and for all of the petroleums studied. This increase in water repellency (WDPT) may result in very long infiltration times causing more run-off, soil erosion, and a diminished capacity of the soil to support vegetative growth (Adams et al. 2008a; Rillig 2005; Moody and Schlossberg 2010). However, for the clayey soil investigated in this study, this problem (in the field) is probably minimal or absent.

\section{Model for estimating WDPT from ${ }^{\circ}$ API and oil concentration}

The use of models can assist in the determination of parameter values that may alter or negatively affect soil fertility. For example, Nawaz et al. (2012) found models very useful in determining soil compaction, a property that in excess impedes water infiltration and root penetration. The data observed in this study also appeared to have characteristics that permitted useful modeling. In a careful evaluation of the logarithmic regression obtained from the repellency persistence data in Fig. 1, which all had $R^{2}>0.902$, one observes a tendency between the coefficients in the equations which was related to the crude oil density ( $\left.{ }^{\circ} \mathrm{API}\right)$. The general form of the regressions observed is shown in Eq. 1:

$Y=A+B \ln (x)$

in which $x$ and $y$ are the crude oil concentration (in \%) and WDPT values (s), respectively. $A$ and $B$ are the coefficients corresponding to the logarithmic functions for each type of crude oil (i.e., 1.802 and 3.437 for light crude, 7.487 and 16.024 for medium crude, and 45.163 and 45.399 for the heavy crude). Both coefficients $A$ and $B$ were independently compared to the API gravity obtaining a first-order equation for coefficient $A$ and a zero-order equation for coefficient $B$. Both of these relations had correlations of $R^{2}>0.980$ (Fig. 3).

The equations from the regressions of $[\ln ($ coefficient $A$ ) vs. ${ }^{\circ} \mathrm{API}$ ] and [coefficient $B$ vs. ${ }^{\circ} \mathrm{API}$ ] were used to calculate the coefficients $A$ and $B$ corresponding to a particular type of crude oil. These values were then used in the general Eq. 1 to calculate the WDPT corresponding to a particular concentration and density of oil in soil. An example of this type of calculation is shown below for a concentration of $1 \%$ of light crude oil with gravity of $36.6^{\circ} \mathrm{API}$.

Calculation of coefficient $A$ :

$y=6.0585-0.1489 x$

where $x$ and $y$ are ${ }^{\circ} \mathrm{API}$ and $\ln (\operatorname{coefficient} A)$, respectively.

Substituting these values:

$\operatorname{Ln}(\operatorname{coef} . A)=6.0585-0.1489\left(36.6^{\circ} \mathrm{API}\right)$

$\operatorname{Ln}(\operatorname{coef} . A)=0.60876$

$A=\mathrm{e}^{(0.60876)}$

$A=1.83815$

Calculation of coefficient $B$ :

$y=7.341-1.9667 x$

where $x$ and $y$ are ${ }^{\circ} \mathrm{API}$ and coefficient $B$, respectively.

Substituting these values:

Coef. $B=73.41-1.9667\left(36.6^{\circ} \mathrm{API}\right)$

$B=1.42878$

The values of these coefficients $(A$ and $B)$ were then used in Eq. 1 to determine the corresponding soil water repellency (WDPT). Since the petroleum concentration in this sample calculation is $1 \%$, we then use this value to calculate the water repellency (WDPT):

Substituting values:

$$
\begin{aligned}
\text { WDPT } & =1.83815+1.42878(\ln 1) \\
\text { WDPT } & =1.83815
\end{aligned}
$$

This series of procedures was used to calculate the expected water repellency (WDPT) for all of the experimental data, at the three API gravities
Fig. 3 Correlation between regression coefficients and ${ }^{\circ} \mathrm{API}$
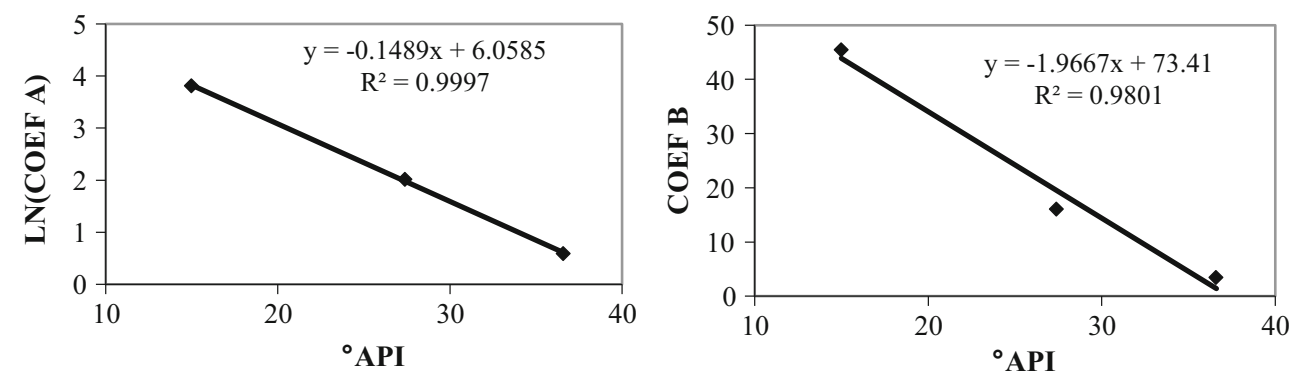


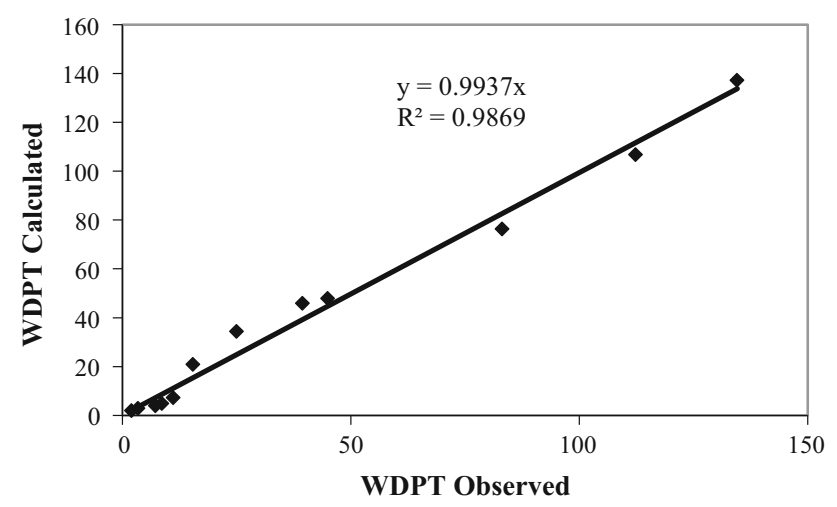

Fig. 4 Correlation between calculated and observed WDPT values

(corresponding to light, medium, and heavy oil) and at each of the four concentrations $(1,2,4$, and $8 \%)$. The calculated values were then compared to the experimental observations, and the relationship observed in Fig. 4 was found. As seen in this figure, there was an excellent correlation between predicted and actual values $\left(R^{2}=0.986\right)$ in a linear relationship passing through the ordinate. It is important to point out that besides presenting an excellent determination coefficient, when the regression is bound to intercept the ordinate (0), the value of the slope is very nearly $1.0(0.9937)$, indicating practically an equivalence between the calculated values from the model and the observed values.

At least for this particular soil, this model may be a useful tool to estimate the expected persistence of soil water repellency (WDPT) according to two independent variables that can be obtained from soil sampling and laboratory determinations: the concentration of crude petroleum in soil and the API density ( $\left.{ }^{\circ} \mathrm{API}\right)$ of the oil. The petroleum concentration in soil may be obtained by various methods (for example, IR method EPA 418.1 or gravimetric method EPA 1664A, USEPA 1997, 1999). Likewise, the ${ }^{\circ} \mathrm{API}$ of the oil in soil can be obtained using a new dilution extrapolation method; this is especially useful for low concentrations in soil or when the crude petroleum is very weathered (Morales-Bautista et al. 2013). Thus, by measuring these two variables, this model may also be used to calculate the concentration of petroleum in this soil that would not be expected to cause water repellency, according to the API density of the crude petroleum in the soil. Thus, it may be a useful tool to propose remediation criteria, such as maximum permissible concentrations of oil in soil, with respect to the type of oil spilled (or remaining) in the soil, to prevent the water repellency.

In Fig. 5, this type of correlation is presented. The function in the figure corresponds to those values at which there is expected a water repellency (in dry soil) of no more than WDPT $=60 \mathrm{~s}$, so that the water repellency would be

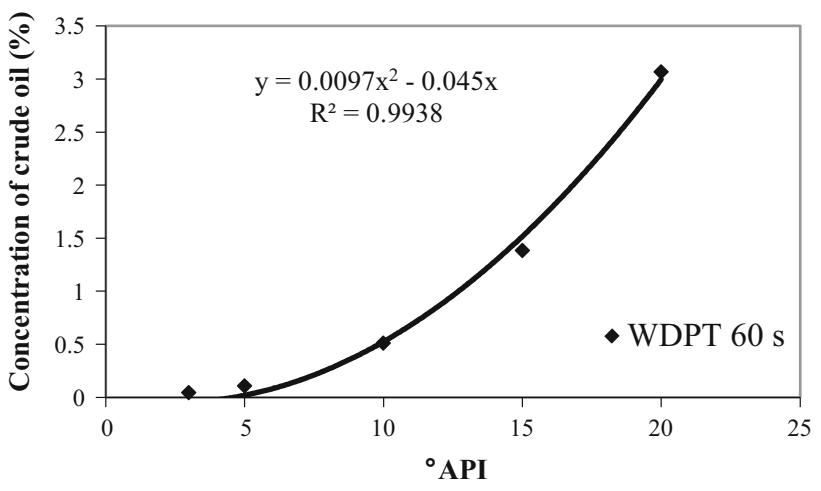

Fig. 5 Correlation between concentrations of crude oil and ${ }^{\circ}$ API for WDPT $\leq 60 \mathrm{~s}$

at most slight [according to the scale proposed by King (1981)]. Values at or below the line in Fig. 5 would, theoretically, be protective of soil fertility by avoiding soil water repellency. Thus, for this kind of clayey soil, one could propose cleanup criteria (maximum permissible concentration) based on the API gravity of the oil remaining in the soil. From this figure, one can also observe that there may be some densities of crude petroleum for which no final concentration in soil would prevent water repellency. In Fig. 5, this occurs (for this soil, when dry) at an API density of about five. Since reducing the concentration of these kinds of heavy crude oils in soil to such low levels may not be technically or economically feasible, other strategies may be useful for soil remediation and restoration. It may be preferable to pursue methods which are directed at overcoming water repellency problems directly, rather than concentrating of technologies focused almost exclusively on reducing the concentration of residual oil in soil. Such strategies have been developed for other clayey, soil-like materials (Guzmán and Adams 2014) by techniques which increase water infiltration rates and water holding capacity, without necessarily reducing the overall petroleum hydrocarbon concentration, by the addition of organic substrates and the promotion of vegetative cover.

Although some authors have shown that in naturally occurring water repellent soils, increasing organic matter concentrations are positively correlated with higher water repellency values (Vogelmann et al. 2013), researchers investigating soils that have become water repellent due to petroleum contamination have found that water repellency is due more to the kind of SOM rather than the amount (Roy and McGill 2000), and that the addition of organic amendments may reduce water repellency by several orders of magnitude, apparently by increasing the water holding capacity of the soil (Córdova 2010, cited in Adams 2011). This may maintain the in situ water content above the critical threshold at which water repellency becomes 
manifest. Similarly, the increase in field capacity was correlated with a reduction in hydrophobicity in soil which have been recovered by phytoremediation techniques (Guzmán and Adams 2014; Sublette et al. 2010).

In addition to the type and amount of SOM being correlated with soil hydrophobicity, texture has also been implicated. Generally, soils with higher clay contents are less likely to suffer water repellency in the field, due to the greater surface area available, and greater water holding capacity (Vogelmann et al. 2013; Roy and McGill 2000). Thus, it is important to exercise caution when using this particular model - applying only to this soil or other, very similar soils in terms quantity and type of clay and organic matter. Apart from these factors, it would appear that at least for this particular soil, the potential for the formation of soil water repellency can be related to the type and concentration of petroleum contamination. In the study, these relationships could be mathematically related to exponential functions in which the hydrophobicity may be determined according to the independent variables of API degrees (related to the specific gravity of the crude oil in the soil) and the petroleum hydrocarbon concentration in soil with a very good correlation $\left(R^{2}=0.986\right)$.

\section{Conclusion}

In this study, the relationship between the water repellency in a clayey soil was compared to the concentration of crude oil in soil, as well as to the API density of the oil. Logarithmic functions, similar to Freundlich absorption isotherms, were observed in which increasing oil concentrations resulted in greater water repellency. Also, the higher the API density of the oil, the increase in water repellency was with respect to concentration was greater. For light crude, all of the concentrations tested resulted in null or only slight water repellency, while with medium crude, all of the concentrations tested resulted in slight water repellency. The soil contaminated with heavy crude presented the highest water repellency values ranging from slight at a $1 \%$ concentration up to severe at all concentrations $\geq 2 \%$. The logarithmic functions could be modeled to produce set of equations in which the expected water repellency could be calculated based on the concentration of oil in soil, and the API density of the oil, with excellent correlation with observed values $\left(R^{2}=0.986\right)$. This method could be used to develop cleanup criteria for soils based on the concentration and density of the residual oil in soil. Critical moisture contents indicated that at least for this kind of clayey soil, water repellency in the field should not present a problem, since even during the driest part of the year, the in situ moisture content remained above the critical moisture content for all but the most contaminated soil with heavy crude. Thus, comparisons between critical moisture content and actual in situ moisture content during the driest part of the year are important for determining the real risk of water repellency in petroleum-contaminated soils.

Acknowledgments Financial support for this research was provided by the Consejo Nacional de Ciencia y Tecnología (National Council of Science and Technology, México) and the Government of Tabasco State, Grant No. Fomix 2009-04, TAB-2009-C18-121493.

\section{References}

Adams RH (2011) Proceso de desorción alcalina—enmienda orgánica para la restauración de suelo contaminado por hidrocarburos y repelente al agua. Patent application no. MX/a/2011/007432, 12-JUL-2011, Instituto Méxicano de la Propiedad Industrial. http://siga.impi.gob.mx/\#busquedas\#operator=all\#search=RAND YHOWARDADAMS\#gaceta $=2 \#$ resultados $=25 \#$ skip $=0$ \#order $=$ relevancia

Adams RH, Guzmán Osorio FJ, Zavala Cruz J (2008a) Water repellency in oil contaminated sandy and clayey soils. Int J Environ Sci Technol 5(4):445-454. http://link.springer.com/ article/10.1007\%2FBF03326040\#page-1

Adams RH, Cruz JZ, Morales GF (2008b) Concentración residual de hidrocarburos en suelos del trópico II: afectación a la fertilidad y su recuperación. Interciencia 33(7):483-489. http://www. redalyc.org/pdf/339/33933703.pdf

Alves AS, Pinho MA, Albergaria JT, Domingues V, Alvim-Ferraz MCM, De Marco P, Delerue-Matos C (2012) Sequential application of soil vapor extraction and bioremediation processes for the remediation of ethylbenzene-contaminated soils. Water Air Soil Pollut 223:2601-2609. http://link.springer.com/content/ pdf/10.1007/s11270-011-1051-y.pdf

Atlas RM (1981) Petroleum degradation of petroleum hydrocarbons: environmental perspective. Microbiol Rev 45(1):180-209. http:// www.ncbi.nlm.nih.gov/pmc/articles/PMC281502/

Ávila ACR (2011) Efectos de los hidrocarburos del petróleo en la fertilidad y toxicidad del suelo arenosol. Tesis de Licenciatura, Universidad Juárez Autónoma de Tabasco, División Académica de Ciencias Biológicas, Villahermosa, Tabasco, México

Bagherzadeh-Namazi A, Shojaosadati A, Hashemi-Najafabadi S (2008) Biodegradation of used engine oil using mixed and isolated cultures. Int J Environ Res 2(4):431-440. http://www. bioline.org.br/pdf?er08057

Barton L, Colmer TD (2011) Granular wetting agents ameliorate water repellency in turfgrass of contrasting soil organic matter content. Plant Soil 348(1):411-424. http://link.springer.com/ article/10.1007\%2Fs11104-011-0765-3\#page-1

Basumatary B, Bordoloi S, Sarma H P (2012) Crude oil-contaminated soil phytoremediation by using Cyperus brevifolius (Rottb) Hassk. Water Air Soil Pollut 223:3373-3383. http://link. springer.com/article/10.1007\%2Fs11270-012-1116-6\#page-1

Bohn HL, McNeal BL, O’Connor GA (1993) Química del suelo. 1ra Ed Limusa Grupo Noriega Editores, México, DF, p 370. http:// books.google.es/books?id=59FtAQAACAAJ\&sitesec=buy\&hl= es\&source $=$ gbs_atb

Clothier BE, Vogeler I, Magesan GN (2000) The breakdown of water repellency and solute transport through a hydrophobic soil. J Hydrol 231-232:255-264. http://www.sciencedirect.com/ science/article/pii/S0022169400001992

Córdova AA (2010) Efecto de los hidrocarburos sobre las propiedades físicas y químicas de suelo y su atenuación mediante la adición 
de cachaza de caña. Tesis de Licenciatura en Ingeniería Ambiental, Universidad Juárez Autónoma de Tabasco, Villahermosa, Tabasco, México

Dekker LW, Ritsema CJ (1994) How water moves in a water repellent sandy soil, part 1: potential and actual water repellency. Water Resour Res 30:2507-2517. http://onlinelibrary.wiley.com/doi/ 10.1029/94WR00749/abstract

Dekker LW, Ritsema C J, Oostindie K (2004) Dry spots in golf courses: occurrence, amelioration and prevention. Acta Hortic 661:99-104. http://www.actahort.org/members/ showpdf?booknrarnr=661_11

Díaz RIJ, Ramírez SH, Gutiérrez RM, Favela TE (2003) Biodegradation of Maya crude oil fractions by bacterial strains and a defined mixed culture isolated from Cyperus laxus rhizosphere soil in a contaminated site. Can J Microbiol 49(12):755-761. http://www.ncbi.nlm.nih.gov/pubmed/15162200

Edenborn HM, Zenone VE (2007) Rapid estimation of TPH reduction in oil-contaminated soils using the MED method. Publication no. DOE/NETL-IR-2007-142. Department of Energy, National Energy Technology Laboratory, Pittsburg. http://www.osti.gov/ scitech/biblio/915479

Freundlich H (1926) Colloid and capillary chemistry. Methuen, London, pp 114-122. http://onlinelibrary.wiley.com/doi/10. 1002/jctb.5000454407/abstract

Goldberg S (2005) Equations and models describing adsorption processes in soil. In: Tabatabai MA, Sparks DL (eds) Chemical processes in soils. Soil Science Society of America, SSSA book series, no. 8, pp 489-517. http://www.ars.usda.gov/ SP2UserFiles/Place/53102000/pdf_pubs/P1721.pdf

Gutiérrez CMC, Zavala CJ (2002) Rasgos hidromórficos de suelos tropicales contaminados con hidrocarburos. Terra Latinoamer 20(2):101-111. http://www.redalyc.org/pdf/573/57320202.pdf

Guzmán OFJ, Adams RH (2014) Mitigation of water repellency in the treatment of contaminated muds using the chemical-biological stabilization process. Int J Environ Sci Technol. doi:10.1007/ s13762-014-0606-z. http://link.springer.com/article/10.1007\% 2Fs13762-014-0606-z\#page-1

Isabell RF (1996) The Australian soil classification. CSIRO, Melbourne, 145 pp. http://www.publish.csiro.au/pid/3529.htm

Jaramillo JDF (2005) Humedad crítica y repelencia al agua en Andisoles colombianos bajo cobertura de Pinus patula Schltdl y Cham. Rev Fac Nal Agr Medellín 58(2):2893-2906. http://www. revistas.unal.edu.co/index.php/refame/rt/printerFriendly/24400/0

Jaramillo JDF (2006) Repelencia al agua en suelos: una síntesis. Rev Ac Colomb Cienc 30(115):215-232. http://www.accefyn.org.co/ revista/Vol_30/115/115_215_232.pdf

King PM (1981) Comparison of methods for measuring severity of water repellence of sandy soils and assessment of some factors that affect its measurement. Aust J Soil Res 19:275-285. http:// www.researchgate.net/publication/240505934_Comparison_of_ methods_for_measuring_severity_of_water_repellence_of_sand y_soils_and_assessment_of_some_factors_that_affect_its_meas urement

Leelamanie DAL, Karube J, Yoshida A (2008) Characterizing water repellency indices: contact angle and water drop penetration time of hydrophobized sand. Soil Sci Plant Nutr 54(2):179-187. http://onlinelibrary.wiley.com/doi/10.1111/j.1747-0765.2007. 00232.x/abstract

Letey J, Carrillo MLK, Pang XP (2000) Approaches to characterize the degree of water repellency. J Hydrol 231-232:61-65. http:// www.sciencedirect.com/science/article/pii/ S0022169400001839\#

Li X, Feng Y, Sawatsky N (1997) Importance of soil-water relationships in assessing the endpoint of bioremediated soil I: plant growth. Plant Soil 192(2):219-226. http://link.springer. com/article/10.1023\%2FA\%3A1004280626976\#page-1
Litvina M, Todoruk T, Langford CH (2003) Composition and structure of agents responsible for development of water repellency in soils following oil contamination. Environ Sci Technol 37(13):2883-2888. http://www.ncbi.nlm.nih.gov/ pubmed/12875390

Lu M, Zhang Z, Sun S, Wei X, Wang Q, Su Y (2010) The use of goosegrass (Eleusine indica) to remediate soil contaminated with petroleum. Water Air Soil Pollut 209:181-189. http://link. springer.com/article/10.1007\%2Fs11270-009-0190-x\#page-1

Moody DR, Schlossberg MJ (2010) Soil water repellency index prediction using the molarity of ethanol droplet test. Vadose Zone J 9(4):1046-1051. https://www.soils.org/publications/vzj/ pdfs/9/4/1046

Morales-Bautista CM, Adams RH, Guzmán-Osorio F, Marín-García D (2013) Dilution-extrapolation hydrometer method for easy determination of API gravity of heavily weathered hydrocarbons in petroleum contaminated soil. Energy Environ Res 3(1):115-124. http://www.ccsenet.org/journal/index.php/eer/ article/view/25021

Nawaz MF, Bourrié G, Trolard F (2012) Soil compaction impact and modelling, a review. Agron Sustain Dev 33(2):291-309. http:// link.springer.com/article/10.1007\%Fs13593-001-0071-8

Nieber J, Severson L, Grewe N (2011) Hydrologic characteristics of contaminated soils at the national crude oil spill fate and natural attenuation research site. In: Geological Society of America annual meeting, Minneapolis, MN, 9-12 October, paper 136-1. https://gsa.confex.com/gsa/2011AM/finalprogram/abstract_ 193916.htm

Onwurah INE, Ogugua VN, Onyike NB, Ochonogor AE, Otitoju OF (2007) Crude oil spills in the environment, effects and some innovative clean-up biotechnologies. Int $\mathbf{J}$ Environ Res 1(4):307-320. http://www.bioline.org.br/abstract?id=er07041

Palma LDJ, Triano AS (2007) Plan de uso sustentable de los suelos de Tabasco. Vol II, 2da Reimpresión, Fundación Produce Tabasco, Colegio de Posgraduados-ISPROTABA-FUPROTAB, Villahermosa, Tabasco, México, p 180. http://books.google.com.mx/ books?id=5GCgYgEACAAJ\&sitesec=buy\&hl=es\&source=gbs_ atb

Peel MC, Finlayson BL, McMahon TA (2007) Updated world map of the Köppen-Geiger climate classification. Hydrol Earth Syst Sci 11:1633-1644. http://www.hydrol-earth-syst-sci.net/11/1633/ 2007/hess-11-1633-2007.pdf

Pires LS, Silva MLN, Curi N, Leite FP, Brito LD (2006) Water erosion in post-planting eucalyptus forests at center-east region of Minas Gerais State, Brazil. Pesquisa Agrop Brasil 41(4):687-695. http://www.scielo.br/pdf/pab/v41n4/29818.pdf

Porta J, López AM, Roquero C (1999) Edafología para la agricultura y el medio ambiente, $2^{\mathrm{a}}$ Ed Mundi-Prensa Madrid. http://books. google.com.mx/books?id=GazqVtlTqLUC\&sitesec=buy\&hl= es\&source $=g b s \_a t b$

Quyum, A (2000) Water migration through hydrophobic soils. Master of Science thesis, Department of Civil Engineering, University of Calgary, Calgary, AB, Canada. http://www.collectionscanada. gc.ca/obj/s4/f2/dsk3/ftp05/MQ65008.pdf

Regalado CM, Ritter A, Socorro AR, Pérez-Buenafuente A (2005) Parámetros para la caracterización óptima de la repelencia en la zona no saturada. In: Samper Calvete FJ, Paz González A (eds) Estudios de la zona no saturada del suelo, vol VII. Universidad de la Coruña, Coruña, Spain, pp 87-93. http://www. zonanosaturada.com/publics/ZNS05/area_1/15.pdf

Rillig CM (2005) A connection between fungal hydrophobins and soil water repellency? Pedobiologia 49:395-399. http://www.dbs. umt.edu/dbs/research_labs/rilliglab/Rillig\%202005\% 20Pedobiologia.pdf

Roy JL, McGill WB (1998) Characterization of disaggregated nonwettable surface soils found at old crude oil spill sites. Can 
J Soil Sci 78(2):331-334. http://pubs.aic.ca/doi/pdf/10.4141/ S97-039

Roy JL, McGill WB (2000) Investigation into mechanisms leading to the development, spread and persistence of soil water repellency following contamination by crude oil. Can J Soil Sci 80:595-606. http://aic.ca/doi/abs/10.4141/S99-091

Roy JL, McGill WB (2002) Assessing soil water repellency using the molarity of ethanol droplet test. Soil Sci 167(2):83-97. http:// journals.lww.com/soilsci/pages/articleviewer.aspx?year=2002\&i ssue $=02000 \&$ article $=00001 \&$ type $=$ abstract

Schlossberg MJ, McNitt AS, Fidanza MA (2005) Development of water repellency in sand-based root zones. Int Turfgrass Soc Res J 10:1123-1130. https://getinfo.de/app/DEVELOPMENT-OFWATER-REPELLENCY-IN-SAND-BASED-ROOT/id/BLCP\% 3ACN057411764

Secretaría de Medio Ambiente y Recursos Naturales (SEMARNAT) (2002) Norma Oficial Mexicana NOM-021-SEMARNAT-2000, que establece las especificaciones de fertilidad, salinidad y clasificación de suelos, estudio, muestreo y análisis. Diario Oficial de la Federación, México, DF. http://www.profepa.gob. mx/innovaportal/file/3335/1/nom-021-semarnat-2000.pdf

Shakesby RA, Doerr SH, Walsh RPD (2000) The erosional impact of soil hidrophobicity: current problems and future research directions. J Hydrol 231/232:178-191. http://www. sciencedirect.com/science/article/pii/S0022169400001931\#

Sublette K, Key KC, Bovaird B (2010) Combating hydrophobicity in the revegetation of hydrocarbon-impacted soils. In: 17th annual international petroleum biofuels environmental conference, San Antonio, TX, August 30-September 2. http://ipec.utulsa.edu/ Conf2010/Abstracts_2010/Sublette_Combating_101.pdf
US Environmental Protection Agency (USEPA) (1997) Test methods for evaluating solid waste: physical/chemical methods. Publication no. EPA-530/SW-846. http://www.epa.gov/osw/hazard/ testmethdos/sw846/online/index.htm

US Environmental Protection Agency (USEPA) (1999) Analytical methods-method 1664, revision A: $n$-hexane extractable material (HEM; oil and grease) and silica gel treated $n$-hexane extractable material (SGT-HEM; non-polar material) by extraction and gravimetry. Publication no. EPA-821-R-98-002. http:// water.epa.gov/scitech/methods/cwa/oil/upload/2007_07_10_ methods_method_ol_1664.pdf

Vogelmann ES, Riechert JM, Prevedello J, Consensa COB, Oliveira AÉ, Awe GO, Mataix-Solera J (2013) Threshold water content beyond which hydrophobic soils become hydrophilic: the role of soil texture and organic matter. Geoderma 209-2010:177-187. http://www.sciencedirect.com/science/article/pii/ S001670611300219X

Volke ST, Velasco TJA (2002) Tecnologías de remediación para suelos contaminados. Instituto Nacional de Ecología, México DF. http://www.inecc.gob.mx/descargas/publicaciones/372.pdf

West RC, Psuty NP, Thom BG (1987) Las tierras bajas de Tabasco en el Sureste de México, Gobierno del Estado de Tabasco, Villahermosa, Tabasco, México. http://books.google.com.mx/ books id=sMpoAAAAMAAJ $\&$ sitesec $=$ buy $\&$ hl $=$ es $\&$ source $=\mathrm{gbs}$ _vpt_buy

Zahed MA, Aziz HA, Isa MH, Mohajeri L (2010) Enhancement biodegradation of $n$-alkanes from crude oil contaminated seawater. Int J Environ Res 4(4):1735-6865. http://www.sid.ir/ en/VEWSSID/J_pdf/108220100410.pdf 